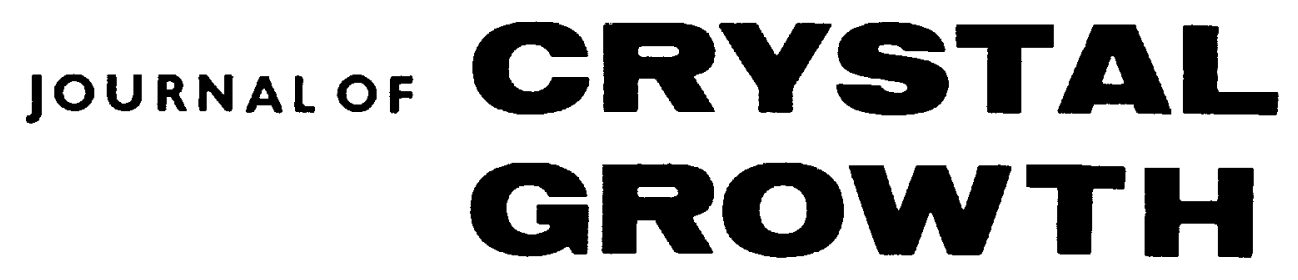

Journal of Crystal Growth 183 (1998) 519-524

\title{
Vapor-phase stoichiometry and heat treatment of CdTe starting material for physical vapor transport
}

Ching-Hua Su ${ }^{\mathrm{a}, *}$, Yi-Gao Sha ${ }^{\mathrm{a}, 1}$, S.L. Lehoczky ${ }^{\mathrm{a}}$, Hao-Chieh Liu ${ }^{\mathrm{b}}$, Rei Fang ${ }^{\mathrm{b}}$, R.F. Brebrick ${ }^{\mathrm{b}}$

${ }^{3}$ Space Sciences Laboratory. NASA/Marshall Space Flight Center, Huntsville, AL 35812, USA

${ }^{\circ}$ Materials Science and Metallurgy Program, Marquette University, Milwaukee, WI 53233, USA

Received 19 April 1997; accepted 18 August 1997

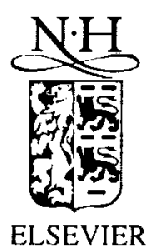




\section{Journal of Crystal Growth}

EDITORIAL BOARD

M. SCHIEBER (Principal Editor)

Hebrew University, Jerusalem 91904 , Israel

Telefax: + 972-2.566 3878

\section{R. KERN}

CRMC $^{2}$, CNRS, Campus Luminy, Case 913

F.13288 Marseille Cedex 9, France

Telefax: + 33-91-4-418916
The Frody and Nadine Herrman

Graduate School of Appl. Sci.

\author{
R.S. FEIGELSON \\ Ctr. Materials Res., $105 \mathrm{McCullough}$ Bldg. \\ Stanford Univ., Stanford, CA 94305-4045, USA \\ Telefax: + [-415-723 3044 \\ T. NISHINAGA \\ Dept. Electron. Eng., Univ. of Tokyo
7-3-1, Hongo, Bunkyo-ku, Tokyo 113, Japan \\ Telefax: + 81-3-5684-3974
}

\section{ASSOCIATE EDITORS}

A. BARONNET (Industrial Biological, Molecular Crystals) CRMC $^{2}$, CNRS, Campus Luminy, Case 913

F-13288 Marseille Cedex 9, France

Telefax: + 33-91-4-418916

K.W. BENZ (Microgravity, Electronic Materials)

Kristallographisches Inst., Universität

Hebelstr. 25, D-79104 Freiburg, Germany

Telefax: + 49-761-203 4369

A.A. CHERNOV (Kinetics of Crystallization, Protein Crystallization) Inst. Crystallography, Acad. of Sciences Leninskii Prosp., Moscow 117333, Russian Fed. Telefax: + 7-095-135011

A.Y. CHO (Molecular Beam Epitaxy) Room IC-323, AT\&T Bell Laboratories Murray Hill, NJ 07974-2070, USA Telefax: + 1-908-582 2043

\section{B. COCKAYNE (IOCG News)}

School of Metallurgy and Mater.

Univ. Birmingham, P.O. Box 363

Edgbaston, Bitmingham, B15 2TT, UK

Telefax: + 44-121-4712207

S.R. CORIELL (Theory)

A153 Mater, Natl. Inst. of Standards \& Technol

Gaithersburgh, MD 20899-0001, USA

Telefax: + 1-301-975-4553

J.J. DER BY (Computational models)

Dept. Chem. Eng \& Mater. Sei., Univ. Minnesota

151 Amundson Hall, 421 Washington Ave. S.E.

Minneapolis, MN 55455-0132, USA

Telefax: + 1.612-6267246

M.E. GLICKSMAN (Solidification)

School of Eng., Mater. Eng. Dept.

Rensselaer Polytechnic Inst

Troy, NY 12180-3590, USA

Telefax: + 1-518-2768554

M.A.G. HALLIWELL ( $X$-ray Diffraction)

Philips Analytical $X$-ray, Lelyweg

7602 EA Almelo, The Netherlands
T. HIBIYA (Oxides, Melt Thermophysical Properties, Micrograviry)

Fundamental Res. Labs., NEC COR PORATION

34, Miyukigaoka, Tsukuba 305, Japan

Telefax: + 81-298-566136

H. KOMATSU (Proteins Molecular Crystallization, Growth from Solutions)

Inst. Mater. Res., Tohoku Univ.

Telefax: + 81-22-215 2011

T.F. KUECH (Thin Films and Electronic

and Optical Devices)

Dept. Chem. Eng., Univ. Wisconsin-Madison

Madison, WI 53706, USA

Telefax: + I-608-265 3782

A. McPHERSON (Protein Growth)

Dept. Mol. Biol. \& Biochem., Univ. Californi Irvine, CA 92697.3900 USA

Telefax: + [-714-8241954

P.A. MORRIS HOTSENPILLER (Electrooptical

E.I. du Pont de Nemours \& Co., Exp. Station

Wilmington, DE 19888-0358, USA

Telelax: + 1-302-695 1664

J.B. MULLIN (Semiconductors)

EMC, "The Hoo", Brockhill Road

West Malvem, Worcs., WR 14 4DL, UK

Telefax: + 44-1684-575 591

K. NAKAJIMA (Liquid and Vapor Phase Epitaxy) Integrated Mater. Lab., Fujitsu Labs. Ltd. Morinosato-Wakamiya 10-1, Atsugi 243-01, Japan Telefax $+81-462-483473$

H. OHNO (Epttaxy)

Research Inst. of Electrical Commun.

Tohoku Univ., Sendai 98077 , Japan

Telefax: + 81.22-2175553

K. PLOOG (Molecular Beam Epitaxy)

Paul-Drude-Inst. für Festkörperelektronik

Telefax: + 49-30-203 77201
Katahira 2-1-1, Sendai 980, Japan

Crystals, Book Reviews, Oxide Thin Films)

Hausvogteiplatz 5-7, D-10117 Berlin, German
D.T.J. HURLE

H.H. Wills Phys. Lab., Univ. Bristo

Tyndall Avenue

Bristol BS8 1TL, UK

G.B STRINGFELLOW

Dept. Mater. Sci. 304 EMRO, Univ, of Utah

Salt Lake City, UT 84112, USA

Telefax: + $1.801-5814816$
R.W. ROUSSEAU (Solution Growth

Industrial Crystallizarion)

School of Chem. Eng. Georgia Inst. of Technol.

Atlanta, GA 30332-0100, USA

Telefax: + 1.404-B94 2866

K. SATO (Biocrystallization and

Organic Crystals)

Fac. Appl. Biol. Sci., Hiroshima Univ.

Higashi-Hiroshima 724, Japan

Telefax: + 81-824-227062

L.F. SCHNEEMEYER (Superconductivity,

Oxides, Novel Materials

Room 1A-363, AT\&T Bell Labs.

Murray Hill, NJ 07974-2070, USA

Telefax: + 1-908-582 2521

D.W. SHAW (Semiconductors, Epitaxy, Devices)

Univ. Texas, 10009 Apple Creek Dr.

Dallas, TX 75243, USA

Telefax: $+1972-2342648$

SUNAGAWA (Minerals)

3-54-2 Kashiwa-cho, Tachikawa-shi

Tokyo 190, Japan

Telefax: + 81-425-353637

G. VAN TENDELOO (Electron Microscopy,

Fullerenes, Superconductivity)

University of Antwerp, RUCA

Groenenborgerlaan 171, B-2020 Antwerp-Belgium

Telefax: + 32-3-2180 217

A.F. WITT (Semiconductor Crystals)

Dept. of Metall. \& Mater. Sci. Massachusetts

Inst. of Technol., Cambridge, MA 02139, USA

Telefax: + $1-617.2535827$

A. ZANGWILL (Theory (Epitaxy)

School of Physics, Georgia Inst. of Technol.

Atlanta, GA 30332 , USA

Telefax: + 1-404-8949958

\section{Scope of the Journa!}

Experimental and theoretical contributions are invited in the following fields: Theory of nucleation and growth, molecular kinetics and transport phenomena, crystallization in viscous modia such as polymers and glasses. Crystal growth of metals, minerals, semiconductors, magnetics, inorganic, organic and biological substances in bulk or as thin films. Apparatus instrumentation and techniques for crystal growth and purification methods. Characterization of single crystals by physical and chemical methods.

\section{Abatracted/Indexed in:}

Aluminium Industry Abstracts; Chemical Abstracts; Current Contents; Physical, Chemical and Earth Sciences; EI Compendex Plus; Engineered Materials Abstracts Enginocring Index; INSPEC; Metals Abstracts.

\section{Subecription Information 1998}

Volumes 182-194 of Journal of Crystal Growth (ISSN 0022-0248) are scheduled for publication. (Frequency: semimonthly.) Prices are available from the publishers upon request. Subscriptions are accepted on a prepaid basis only. Issues are sent by SAL (Surface Air Lified) mail wherever this service is available. Airmail rates are available upon request. Please address all enquiries regarding orders and subscriptions to:

Elsevier Science, B.V., Order Fulfilment Department

P.O. Box 211, 1000 AE Amsterdam, The Netheriands Tel: +3120485 3642; Fax: +31204853598

Claims for issues not received should be made within six months of our publication (mailing) date.

US mailiag sotice-Journal of Crystal Growth (ISSN 0022-0248) is published semimonthly by Elsevier Science B.V., Molenwerf 1, P.O. Box 211 , 1000 AE Amsterdam, The Netherlands. Annual subscription price in the USA is US $\$ 7607$ (valid in North, Central and South America only), including air speed delivery. Periodicals postage paid at Jamaica

US postmasters: Send address changes to Journal of Crystal Growth, Publications Expediting. Inc., 200 Meacham Avenue, Elmont NY 11003 . Airfreight and mailing in the USA by Publications Expediting

$@$ The paper used in this publication meets the requirements of ANSI/NISO Z39.48-1992 (Permanence of Paper)

PRINTED IN THE NETHERLANDS 


\begin{abstract}
NASA/CR- $-1998-207454$
A.SPi

$1 N-76-C R$

(E) $A$ AUED

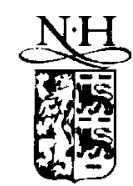

ELSEVIER

Journal of Crystal Growth 183 (1998) 519-524

Crystal

GROWTH

\section{Vapor-phase stoichiometry and heat treatment of CdTe starting material for physical vapor transport}

\author{
Ching-Hua Su ${ }^{a, *}$, Yi-Gao Sha ${ }^{a, 1}$, S.L. Lehoczky ${ }^{a}$, Hao-Chieh Liu ${ }^{b}$, Rei Fang ${ }^{b}$, \\ R.F. Brebrick ${ }^{\mathrm{b}}$ \\ "Space Sciences Laboratory, NASA/Marshall Space Flight Center, Huntsville, AL 35812, USA \\ ${ }^{\mathrm{b}}$ Materials Science and Metallurgy Program, Marquette University, Milwaukee, WI 53233, USA
}

Received 19 April 1997; accepted 18 August 1997

Abstract

Six batches of CdTe, having total amounts of material from 99 to $203 \mathrm{~g}$ and gross mole fraction of $\mathrm{Te}, \mathrm{X}_{\mathrm{Te}}$, 0.499954-0.500138, were synthesized from pure $\mathrm{Cd}$ and $\mathrm{Te}$ elements. The vapor-phase stoichiometry of the assynthesized CdTe batches was determined from the partial pressure of $\mathrm{Te}_{2}, P_{\mathrm{Te}_{2}}$, using an optical absorption technique. The measured vapor compositions at $870^{\circ} \mathrm{C}$ were Te-rich for all of the batches with partial pressure ratios of $\mathrm{Cd}$ to $\mathrm{Te}_{2}$, $P_{\mathrm{Cd}} / P_{\mathrm{Te}_{2}}$, ranging from 0.00742 to 1.92 . After the heat treatment of baking under dynamic vacuum at $8700^{\circ} \mathrm{C}$ for $8 \mathrm{~min}$, the vapor-phase compositions moved toward that of the congruent sublimation, i.e. $P_{\mathrm{Cd}} / P_{\mathrm{Tc}_{2}}=2.0$, with the measured $P_{\mathrm{Cd}} / P_{\mathrm{Tc}_{2}}$ varying from 1.84 to 3.47 . The partial pressure measurements on one of the heat-treated samples also showed that the sample remained close to the congruent sublimation condition over the temperature range $800-880^{\circ} \mathrm{C}$. C 1998 Elsevier Science B.V. All rights reserved.
\end{abstract}

\section{Introduction}

The partial pressures of the species II and $\mathrm{VI}_{2}$ in equilibrium with the II-VI semiconducting compounds, at a fixed temperature, can vary over orders of magnitude as the composition of the compound varying over the narrow homogeneity

\footnotetext{
${ }^{*}$ Corresponding author. Fax: + 1205544 8762; c-mail: ching.hua.su@msfc.nasa.gov.

${ }^{1}$ Universities Space Research Association, Current address: Digirad Corporation, 7408 Trade St., San Diego, CA 921212410 , USA.
}

range from Group II saturation to Group VI saturation $[1-3]$. As a result, the transport rate of the vapor species in the physical vapor transport (PVT) process can also vary from a maximum transport rate corresponding to the condition of congruent sublimation for the solid phase to transport rates which are orders of magnitude lower when the solid composition deviates significantly from congruent sublimation. A precise control on the stoichiometry of the starting compound from the weighing of the constituent elements is practically impossible. Nevertheless, with certain heat-treatment methods the partial pressures over the starting compound material can be reasonably reproduced for the

0022-0248/98/\$19.00 C 1998 Elsevicr Science B.V. All rights reserved. PII S0022-0248(97)00504-6 
congruent sublimation condition. One of the methods to adjust the stoichiometry of the starting material is to bake out the material at the processing temperature under a dynamic vacuum condition. However, the effectiveness of the heat treatment on the vapor-phase composition was never reported nor confirmed. The direct way to determine vapor-phase stoichiometry is by measurement of the partial pressures coexisting with the sample. Using an optical absorption technique, Brebrick and co-workers have reported partial pressure data over the systems of $\mathrm{HgTe}[4,5]$, $\mathrm{HgSe}[6], \mathrm{CdTe}[3,7], \mathrm{ZnTe}[2], \mathrm{ZnSe}[8,9], \mathrm{PbTe}$ $[10,11]$, SnTe $[12,13]$, PbSnTe [13], HgCdTe [14-16] and $\mathrm{HgZnTe}$ [17]. In this paper, using the same optical absorption technique, we report the effectiveness of the heat treatment by measuring the partial pressures of $\mathrm{Te}_{2}, P_{\mathrm{Te}_{2}}$, over a series of assynthesized CdTe samples as well as $P_{\mathrm{Te}_{2}}$ over these samples after they have been heat treated under dynamic vacuum.

\section{Experimental procedure}

\subsection{Homogenization of $\mathrm{CdTe}$}

The ampoules were made from either $27 \times 25$ ( $27 \mathrm{~mm} \mathrm{OD,} 25 \mathrm{~mm} \mathrm{ID),} 23 \times 20$ or $22 \times 20 \mathrm{~mm}$ fused silica tubings supplied by Heraeus Amersil, Inc. The ampoules were cleaned and outgassed at $1045^{\circ} \mathrm{C}$ under vacuum for over $16 \mathrm{~h}$ and, except for batch \#13, were then graphitized inside by flowing a mixture of $10 \%$ methane-Ar gas at $1045^{\circ} \mathrm{C}$ for 5-10 min. The starting elements were quadruple zone refined (QZR), six-nine grade, $7 \mathrm{~mm}$ diameter $\mathrm{Cd}$ rods and QZR, six-nine grade Te bars from Johnson Matthey, Inc. The Cd bars were cut into approximately $1.5 \mathrm{~cm}$ segments and the Te bars were cut into chunks with typical linear dimensions of $2-4 \mathrm{~mm}$. The elements were weighed to an accuracy of $0.1 \mathrm{mg}$. The ampoules were sealed under vacuum after the elements had been loaded with the $\mathrm{Cd}$ rods surrounded by the Te chunks. The amounts of $\mathrm{Cd}$ and $\mathrm{Te}$ in each ampoule as well as the corresponding gross $\mathrm{Te}$ mole fraction are listed in Table 1. The sealed ampoules were heated inside a furnace with an isothermal heat-pipe liner from room temperature to the homogenization temperatures, $T_{\mathrm{H}}$, in several hours and maintained at $T_{\mathrm{H}}$ for certain hours before cool down. On batch \# 6 the furnace was heated from room temperature to $500^{\circ} \mathrm{C}$ in $1 \mathrm{~h}$ and maintained at $500^{\circ} \mathrm{C}$ for $22 \mathrm{~h}$ before being heated to $925^{\circ} \mathrm{C}$ in $2 \mathrm{~h}$. The homogenization temperature, $T_{\mathrm{H}}$, and the time at $T_{\mathrm{H}}$ are also listed in Table 1. During heat-up the homogenization reaction takes place at the $\mathrm{CdTe}-\mathrm{Te}$ eutectic temperature of $447.2^{\circ} \mathrm{C}$ [18]. The readings of the thermocouple attached to the ampoule jumped from $450^{\circ} \mathrm{C}$ to over $500^{\circ} \mathrm{C}\left(600^{\circ} \mathrm{C}\right.$ on batch \#11) within $1 \mathrm{~min}$ because of the heat from the exothermic eutectic reaction.

\subsection{Heat treatment and partial pressure measurements}

After the homogenization process, the ampoule for each batch was opened and the reacted spongelike $\mathrm{CdTe}$ was crushed, ground and mixed with mortar and pestle into particles of diameter less

Table 1

Amounts of $\mathrm{Cd}$ and $\mathrm{Te}$, the corresponding Te content, the homogenization temperature, $T_{\mathbf{H}}$, and the homogenization duration for each batch

\begin{tabular}{llrrrr}
\hline Batch number & $\mathrm{Cd}(\mathrm{g})$ & $\mathrm{Te}(\mathrm{g})$ & \multicolumn{1}{c}{$X_{\mathrm{Te}}-\frac{1}{2}$} & $T_{\mathrm{H}}\left({ }^{\circ} \mathrm{C}\right)$ & $T_{\mathrm{H}}(\mathrm{h})$ \\
\hline 6 & 61.1715 & 69.4311 & $-4.6 \times 10^{-5}$ & 925 & 63 \\
7 & 71.1613 & 80.7791 & $-1.7 \times 10^{-5}$ & 925 & 16 \\
9 & 64.3485 & 73.0792 & $9.8 \times 10^{-5}$ & 955 & 64 \\
10 & 77.0927 & 87.5088 & $-2.6 \times 10^{-5}$ & 1015 & 39 \\
11 & 95.1116 & 107.9900 & $3.8 \times 10^{-5}$ & 985 & 40 \\
13 & 46.5623 & 52.8885 & $13.8 \times 10^{-5}$ & 940 & 21 \\
\hline
\end{tabular}


than $0.5 \mathrm{~mm}$. The T-shape cells for the optical absorption measurement were made of fused silica with path lengths varying from 18 to $30 \mathrm{~mm}$. The cells were cleaned and outgassed at $1000-1030^{\circ} \mathrm{C}$ for over $16 \mathrm{~h}$ before loading the samples. One set of the optical cells was loaded with the ass-synthesized material from various batches and sealed under vacuum. The other cells were loaded with the assynthesized materials followed by a heat-treatment process to adjust the stoichiometry prior to seal off. The heat treatment of these cells was performed by baking out the loaded cell at the processed temperature under dynamic vacuum. Table 2 lists the cell number (corresponding to the CdTe batch), the amounts of CdTe loaded, the bake-out temperature and the bake-out duration for each optical cell. The amounts of CdTe as well as the bake-out temperatures were selected to match the parameters usually employed in our laboratory for the crystal growth of CdTe by physical vapor transport. The loss of the material during the baking process under vacuum was reasonable. After baking at $870^{\circ} \mathrm{C}$ for $8 \mathrm{~min}$ the loss of a typical $18 \mathrm{~g}$ charge of $\mathrm{CdTe}$ was 1.8 g, i.e. about $10 \%$.

The basic principles for the partial pressure measurements and the experimental procedure have been described in detail in Refs. [2-17]. In brief, the sample beam of a double-beam monochromator travelled along the top of a constant temperature $\mathrm{T}$-shaped cell and passed through the optical windows. During measurements, the sample, located at the bottom of the vertical leg of the T-shaped cell, was held at one of a set of temperatures lower than the optical path temperature. The optical absorbance was measured between 190 and $800 \mathrm{~nm}$ and the partial pressures of individual vapor species were calculated using the data determined from the calibration runs with pure elements in the cells. As mentioned in the Introduction, the predominant vapor species in equilibrium with condensed $\mathrm{CdTe}$ are $\mathrm{Cd}$ and $\mathrm{Te}_{2}$. All other thermodynamically possible Te monomer or polymers have partial pressures at least two orders of magnitude lower than that of $\mathrm{Te}_{2}$ under the processing temperature and condition. Therefore, only the Te dimer will be considered in the measurements of stoichiometry. For all the cells the measurements indicated that the samples were either Te-rich or near congruent sublimation. Under these conditions the $238.7 \mathrm{~nm}$ atomic $\mathrm{Cd}$ absorption peak was not strong enough to give accurate measurements of $P_{\mathrm{Cd}}$. The partial pressures of $\mathrm{Te}_{2}$ were taken as the average of several values calculated from the Beer's law constants established in the calibration runs of pure Te for the wavelengths between 363.4 to $537.2 \mathrm{~nm}$ [16]. For each cell the partial pressure of $\mathrm{Te}_{2}$ was measured while the sample was held at $870^{\circ} \mathrm{C}$ and the optical cell was at $900^{\circ} \mathrm{C}$. The base line was established with the sample at $400^{\circ} \mathrm{C}$. Each cell was held at an $870^{\circ} \mathrm{C}$ sample temperature for at least $24 \mathrm{~h}$ prior to the measurements.

Table 2

Amounts of CdTe loaded, heat-treatment conditions, the measured partial pressure of $\mathrm{Te}_{2}, P_{\mathrm{Tr}_{2}}$, and the calculated pressure ratio, $P_{\mathrm{Cd}^{\prime}} / P_{\mathrm{Te}_{2}}$, at $870^{\prime} \mathrm{C}$ for as-synthesized and heat treated batches

\begin{tabular}{|c|c|c|c|c|c|}
\hline Cell & Amount of CdTe $(\mathrm{g})$ & $\begin{array}{l}\text { Heat-treatment } \\
\text { temperature }\left({ }^{\circ} \mathrm{C}\right)\end{array}$ & $\begin{array}{l}\text { Heat-treatment } \\
\text { duration (min) }\end{array}$ & $\begin{array}{l}P_{\mathrm{Te}_{2}}(\mathrm{~atm}) \\
\text { at } 870^{-} \mathrm{C}\end{array}$ & $\begin{array}{l}P_{\mathrm{Cd}^{\prime}} P_{\mathrm{Te}_{2}} \\
\text { at } 870^{\circ} \mathrm{C}\end{array}$ \\
\hline 6 & 15.0 & - & - & $4.06 \times 10^{-3}$ & 1.92 \\
\hline 7 & 15.0 & - & - & $1.65 \times 10^{-1}$ & 0.00742 \\
\hline $7 \mathrm{~A}$ & 13.0 & 870 & 8 & $3.44 \times 10^{-3}$ & 2.47 \\
\hline 9 & 12.4 & - & - & $8.90 \times 10^{-2}$ & 0.0187 \\
\hline 10 & 14.9 & - & - & $4.95 \times 10^{-3}$ & 1.43 \\
\hline $10 \mathrm{~A}$ & 20.3 & 870 & 8 & $2.74 \times 10^{-3}$ & 3.47 \\
\hline 11 & 6.9 & - & - & $1.51 \times 10^{-2}$ & 0.268 \\
\hline $11 \mathrm{~A}$ & 20.0 & 860 & 8 & $2.96 \times 10^{-3}$ & 3.11 \\
\hline $13 \mathrm{~A}$ & 17.9 & 800 & 8 & $4.18 \times 10^{-3}$ & 1.84 \\
\hline
\end{tabular}




\section{Results}

The measured partial pressure of $\mathrm{Te}_{2}$ at $870 \mathrm{C}$ for each optical cell is given in the 5th column of Table 2. The given values were usually the average of two measurements obtained after the cells were at temperature for 24 and $48 \mathrm{~h}$. The corresponding partial pressures of $\mathrm{Cd}$ can be obtained from the stoichiometric invariant, $\Delta G_{f}$, the Gibbs energy of formation of CdTe from the vapor phase [19]:

$$
\begin{aligned}
\Delta G_{\mathrm{f}} & =R T \ln \left(P_{\mathrm{Cd}} P_{\mathrm{Te}_{2}}^{1 / 2}\right) \\
& =-68640+44.94 T(\mathrm{cal} / \mathrm{mol}) .
\end{aligned}
$$

The stoichiometry of the vapor phase at $870^{\circ} \mathrm{C}$, defined as $P_{\mathrm{Cd}} / P_{\mathrm{Te}_{2}}$, was then calculated for each cell using the measured $P_{\mathrm{Te}_{2}}$ and the calculated $P_{C d}$ and is given in the last column of Table 2 .

The vapor-phase stoichiometry at temperatures other than $870^{\circ} \mathrm{C}$ was also measured for cell $10 \mathrm{~A}$ and is plotted in Fig. 1. The first series of measured $P_{\mathrm{Te}_{2}}$ is shown as open circles and was started at about $825^{\circ} \mathrm{C}(1000 / T=0.91)$. Several measurements were taken when the sample temperature was increasing to above $880 \mathrm{C}$ before the sample was cooled to $795 \mathrm{C}$. The second series of measurements is shown as solid squares and agreed well with the results of the first series. The time between each run is also given in the figure. The solid line shown is the $P_{\mathrm{Te}_{2}}$ for the congruent sublimation condition, i.e. $P_{\mathrm{Cd} /} / P_{\mathrm{Te}_{2}}=2.0$.

\section{Discussion}

- The measured partial pressures of $\mathrm{Te}_{2}$ over various as-synthesized $\mathrm{CdTe}$ batches, having total amounts of material from 99 to $203 \mathrm{~g}$ and gross Te mole fraction, $X_{\mathrm{Te}}$, from 0.499954 to 0.500138 , show that the vapor compositions at $870 \mathrm{C}$ were always Te-rich. The $P_{\mathrm{Te}_{2}}$ in equilibrium with four CdTe samples of known condensed-phase compositions have previously been measured over the temperature range $635-1025 \mathrm{C}[7]$. The measured $P_{\mathrm{Te}_{2}}$ at $870 \mathrm{C}$ and the corresponding Te contents for these four samples were scaled from Figs. 2 and 4 of Ref. [7], respectively, and are tabulated in Table 3. By comparing the measured $P_{\mathrm{T}_{c_{2}}}$ of our

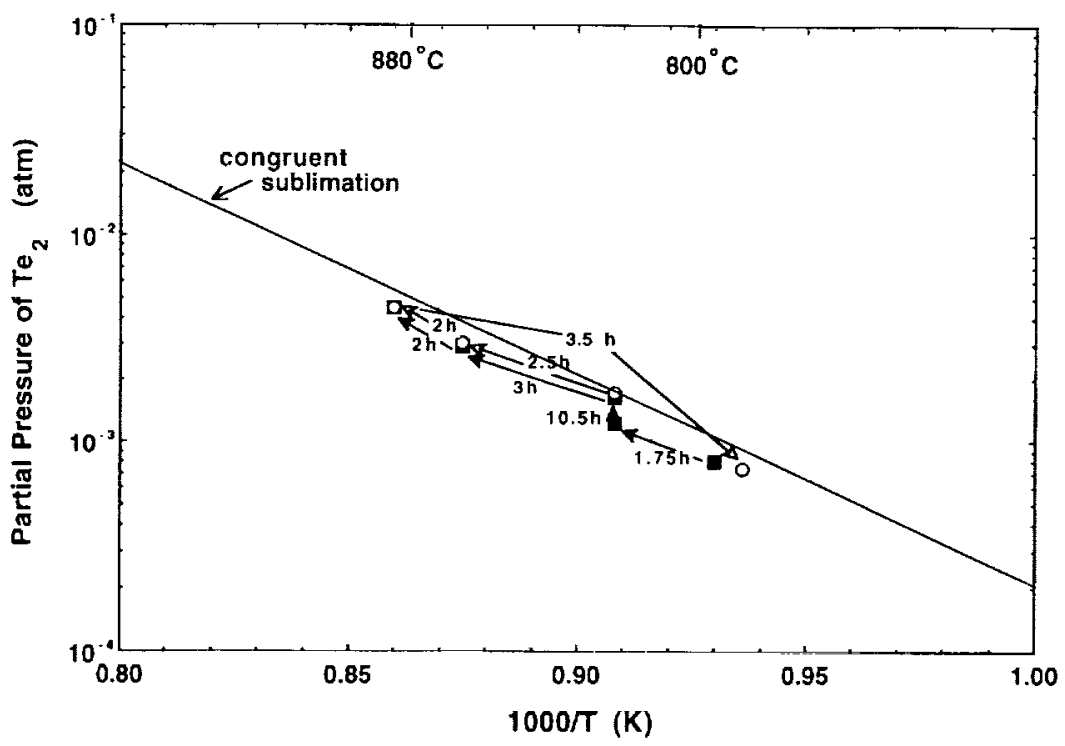

Fig. 1. The measured $P_{\mathrm{Tc}}$ as a function of $1000 / T$ for cell $10 \mathrm{~A}$. The first series of measured $P_{\mathrm{Te}}$ is shown as open circles and was started at about $825^{\circ} \mathrm{C}(1000 / T=0.91)$. Several measurements were taken when the sample temperature was increasing to above $880^{\circ} \mathrm{C}$ before the sample was cooled to $795^{\circ} \mathrm{C}$. The second series of measurements is shown as solid squares. The time between each run is also given. 
Table 3

Te mole fraction, $X_{\mathrm{Tc}}$ and measured $P_{\mathrm{Te}_{2}}$ at $870 \mathrm{C}$ for $\mathrm{CdTe}$ samples from Ref. [7]

\begin{tabular}{lll}
\hline Samples & $X_{\mathrm{Tc}}-\frac{1}{2}$ & $P_{\mathrm{Te}_{2}}(\mathrm{~atm})$ \\
\hline CT-93E & $4.4 \times 10^{-5}$ & 0.135 \\
CT-92A & $2.2 \times 10^{-5}$ & 0.105 \\
CT92-C & $1.4 \times 10^{-5}$ & 0.0595 \\
CT92-D & $1.2 \times 10^{-5}$ & 0.0306 \\
Congruent sublimation $^{\mathrm{a}}$ & $0.3 \times 10^{-5}$ & 0.00396 \\
\hline
\end{tabular}

${ }^{\mathrm{a}}$ Ref. [20].

as-synthesized samples with those in Table 3 , it can be concluded that (a) the samples in cell \#6 and \# 10 were near the congruent sublimation composition at $870^{\circ} \mathrm{C}$ (from a defect chemistry analysis, [20], this congruent sublimation composition is $\left.\left(X_{\mathrm{Te}}-\frac{1}{2}\right)=0.3 \times 10^{-5}\right)$; (b) having $P_{\mathrm{Te}_{2}}=$ $0.165 \mathrm{~atm}$ at $870^{\circ} \mathrm{C}$ the sample in cell \#7 was almost Te-saturated with $\left(X_{\mathrm{Te}}-\frac{1}{2}\right)$ greater than $4.4 \times 10^{-5}$ (note: the equilibrium $P_{\mathrm{Te}_{2}}$ for $\mathrm{Te}$ saturated condition at $870^{\circ} \mathrm{C}$ is $0.18 \mathrm{~atm}$ [7]); (c) the sample in cell \#9, with the measured $P_{\mathrm{Te}_{2}}=0.089 \mathrm{~atm}$ at $870^{\circ} \mathrm{C}$, has composition $\left(X_{\mathrm{Te}}-\frac{1}{2}\right)$ in the range $1.4-2.2 \times 10^{-5}$; (d) the CdTe in cell \#10 and \#11 have $\left(X_{\mathrm{Te}}-\frac{1}{2}\right)$ values below $1.2 \times 10^{-5}$ and above that for congruent sublimation, i.e. $\left(X_{\mathrm{Te}}-\frac{1}{2}\right)=0.3 \times 10^{-5}$, with the value for cell \#10 lower than that for cell \#11. A possible cause for the Te-rich nature of the as-synthesized $\mathrm{CdTe}$ samples is that during the grinding of the synthesized material, occasionally, a small smear of unreacted $\mathrm{Cd}$ element was found and was taken out.

Table 2 clearly shows that after the heat treatment under dynamic vacuum, the vapor-phase compositions moved toward that of congruent sublimation with the measured $P_{\mathrm{Cd}} / P_{\mathrm{Te}_{2}}$ varying from 1.84 to 3.47 . The error associated with the measured $P_{\mathrm{Te}_{2}}$ is estimated to be $15 \%$. With the same error assumed for the $\Delta G_{\mathrm{f}}$ given in Eq. (1), the experimentally measured $P_{\mathrm{Cd}} / P_{\mathrm{Te}_{2}}$ for a congruently subliming $\mathrm{CdTe}$ sample would be in the range 1.38-2.93. The rate-controlling step for the heat treatment should be the solid-state diffusion inside each CdTe particle. The composition of the sample in each cell changed from its original value as outlined in the last paragraph to a value close to that of congruent sublimation during the $8 \mathrm{~min}$ bake out even when the starting composition was near the Te-saturated condition such as the case of cell \#7. The change in composition stopped when the sample reached the congruent sublimation condition because the sample started to lose $\mathrm{Cd}$ and $\mathrm{Te}$ at the same rate through the sublimation process. The required baking time can be estimated from the $\mathrm{CdTe}$ interdiffusion coefficient reported by Brown et al. [21] which gave $D_{\mathrm{CdTe}}=3.4 \times 10^{-5} \mathrm{~cm}^{2} / \mathrm{s}$ at $870^{\circ} \mathrm{C}$. The estimated diffusion length $(D t)^{1 / 2}$ for $8 \mathrm{~min}$ annealing time is $0.128 \mathrm{~cm}$, which is about 5 times the radius of the ground particle. Also, although the heat treatment was performed at $870^{\circ} \mathrm{C}$ the heat-treated sample remains close to the congruent sublimation condition in the temperature range $800-880^{\circ} \mathrm{C}$ as indicated in Fig. 1. This was also evident from the defect chemistry analysis in Ref. [20]; the congruent sublimation composition almost follows a constant $X_{\mathrm{Te}}$ curve for temperatures below $900^{\circ} \mathrm{C}$.

\section{Acknowledgements}

The work was supported by the Microgravity Research Division of the National Aeronautics and Space Administration.

\section{References}

[1] R.C. Sharma, Y.A. Chang, J. Crystal Growth 88 (1988) 193.

[2] R.F. Brebrick, J. Electrochem. Soc. 116 (1969) 1274.

[3] R.F. Brebrick, J. Electrochem. Soc. 118 (1971) 2014.

[4] R.F. Brebrick, A.J. Strauss, J. Phys. Chem. Solids 26 (1965) 989.

[5] C.-H. Su, P.-K. Liao, T. Tung, R.F. Brebrick, High Temp. Sci. 14 (1981) 181.

[6] R.F. Brebrick, J. Chem. Phys. 43 (1965) 3846.

[7] R. Fang, R.F. Brebrick, J. Phys. Chem. Solids 57 (1996) 443.

[8] Y.-G. Sha, C.-H. Su, W. Palosz, M.P. Volz, D.C. Gillies, F.R. Szofran, S.L. Lehoczky, H.-C. Liu, R.F. Brebrick, J. Crystal Growth 146 (1995) 42.

[9] C.-H. Su, Y.-G. Sha, K. Mazuruk, S.L. Lehoczky, H.-C. Liu, R. Fang, R.F. Brebrick, J. Crystal Growth 166 (1996) 736.

[10] Y. Huang, R.F. Brebrick, J. Electrochem. Soc. 135 (1988) 486.

[11] R.F. Brebrick, A.J. Strauss, J. Chem. Phys. 40 (1964) 3230. 
[12] R.F. Brebrick, A.J. Strauss, J. Chem. Phys. 4 I (1964) 197.

[13] Y. Huang, R.F. Brebrick, J. Electrochem. Soc. 135 (1988) 1547.

[14] J.P. Schwartz, T. Tung, R.F. Brebrick, J. Electrochem. Soc. 128 (1981) 438.

[15] T. Tung, L. Golonka, R.F. Brebrick, J. Electrochem. Soc. 128 (I981) $45 \mathrm{I}$

[16] C.-H. Su, P.-K. Liao, R.F. Brebrick, J. Electrochem. Soc. 132 (1985) 942.
[17] K.-T. Chen, Y.-G. Sha, R.F. Brebrick, J. Vac. Sci. Technol. A 8 (1990) 1086.

[18] R.F. Brebrick, C.-H. Su, P.-K. Liao, Semiconductors and Semimetals, vol. 19, Ch. 3, Academic Press, New York, 1983.

[19] R.F. Brebrick, A.J. Strauss, J. Phys. Chem. Solids 25 (1964) 1441.

[20] R.F. Brebrick, R. Fang, J. Phys. Chem. Solids 57 (1996) 451.

[21] M. Brown, A.F.W. Willoughby, J. Crystal Growth 59 (1982) 27. 


\title{
Journal of Crystal Growth
}

\author{
Instructions to Authors (short version)
}

\section{Submission of papers}

Manuscripts (one original + two copies), should be sent to a member of the Editorial Board or preferably to an appropriate subject Associate Editor. News or announcements should be submitted through the Principal Editor; a duplicate should be sent directly to Elsevier Science B.V., address given below.

Original material. Submission of a manuscript implies it is not being simultaneously considered for publication elsewhere and that the authors have obtained the necessary authority for publication.

\section{Types of contributions}

Original research papers, Letters to the Editors and Priority communications are welcome. They should contain an Abstract (of up to 200 words) and a Conclusion section, which particularly in the case of theoretical papers translates the results into terms readily accessible to most readers.

As a guideline: experimental papers should not be longer than 16 double-spaced typed pages, and 8 figures + tables; for theoretical papers a maximum of 20 pages and 10 figures + tables is suggested.

Letters and Priority communications should not be longer than 5 double-spaced typed pages, and 3 figures + tables. They will be given priority in both the refereeing and production processes. The faster production schedule may preclude sending proofs of Letters and Priority communications to authors.

\section{Manuscript preparation}

Contributions may be written in English, French or German. They should have an abstract in English. The paper copies of the text should be prepared with double line spacing and wide margins, on numbered sheets.

Structure. Please adhere to the following order of presentation: Article title, Author(s), Affiliation(s), Abstract, PACS codes and keywords, Main text, Acknowledgements, Appendices, References, Figure captions, Tables.

Corresponding author. The name, complete postal address, telephone and fax numbers and the e-mail address of the corresponding author should be given on the first page of the manuscript.

Classification codes/keywords. Please supply one to four classification codes (PACS and/or MSC) and up to six keywords of your own choice that describe the content of your article in more detail.

References. References to other work should be consecutively numbered in the text using square brackets and listed by number in the Reference list. Please refer to the more detailed instructions for examples.

\section{Illustrations}

Illustrations should also be submitted in triplicate: one master set and two sets of copies. The line drawings in the master set should be original laser printer or plotter output or drawn in black india ink, with careful lettering, large enough (3-5 mm) to remain legible after reduction for printing. The photographs should be originals, with somewhat more contrast than is required in the printed version. They should be unmounted unless part of a composite figure. Any scale markers should be inserted on the photograph itself, not drawn below it.
Colour plates. Figures may be published in colour, if this is judged essential by the Editor. The Publisher and the author will each bear part of the extra costs involved. Further information is available from the Publisher.

\section{After acceptance}

Important. When page proofs of the accepted manuscripts are made and sent out to authors, this is in order to check that no undetected errors have arisen in the typesetting (or file conversion) process. At the proof stage only printer's errors may be corrected. No changes in, or additions to, the edited manuscript will be accepted.

Notification. The authors will receive the final answer of acceptance or rejection from the Office of the Principal Editor and will be invited to supply an electronic version of the accepted text, if this is not already available.

Copyright transfer. In the course of the production process you will be asked to transfer the copyright of the article to the Publisher. This transfer will ensure the widest possible dissemination of information.

\section{Electronic manuscripts}

The Publisher welcomes the receipt of an electronic version of your accepted manuscript. If there is not already a copy of this (on diskette) with the journal editor at the time the manuscript is being refereed, you will be asked to send a file with the text of the accepted manuscript directly to the Publisher by e-mail or on diskette (allowed formats 3.5" or 5.25" MS-DOS, or 3.5" Macintosh) to the address given below. (When e-mailing a non-ASCII word-processor file, you should encode it, e.g. with UUENCODE or BinHex, so as to retain all formatting codes.) The name and version of the word-processing program and the type of operating system should always be indicated. Please note that no deviations from the version accepted by the Editor of the journal are permissible without the prior and explicit approval by the Editor. Such changes should be clearly indicated on an accompanying printout of the file.

\section{Author benefits}

No page charges. Publishing in Journal of Crystal Growth is free.

Free offprints. The corresponding author will receive 50 offprints free of charge. An offprint order form will be supplied by the Publisher for ordering any additional paid offprints.

Discount. Contributors to Elsevier Science journals are entitled to a $30 \%$ discount on all Elsevier Science books.

\section{Further information (after acceptance)}

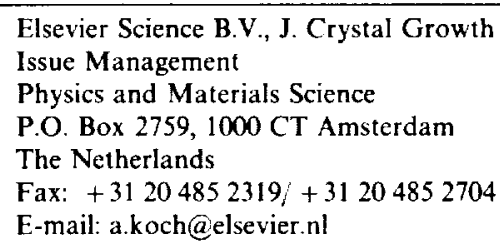


s

$\vdots$ 